\title{
Effects of chondroitin sulfate and sodium hyaluronate on chondrocytes and extracellular matrix of articular cartilage in dogs with degenerative joint disease
}

\author{
[Efeitos do sulfato de condroitina e do hialuronato de sódio nos condrócitos e na matriz extracelular na cartilagem \\ articular de cães com doença articular degenerativa] \\ G. Gonçalves ${ }^{1}$, E.G. Melo ${ }^{2 *}$, M.G. Gomes ${ }^{2}$, V.A. Nunes ${ }^{2}$, C.M.F. Rezende ${ }^{2}$ \\ ${ }^{1}$ Médica veterinária autônoma \\ ${ }^{2}$ Escola de Veterinária - UFMG \\ Caixa Postal 567 \\ 30123-970 - Belo Horizonte, MG
}

\begin{abstract}
Samples of articular cartilage of femur, tibia and patella of 15 dogs with experimentally induced degenerative joint disease (DJD) were microscopically analyzed. Animals were distributed into three groups $(n=5)$ : the control group received no medication; the second group was treated with chondroitin sulfate and the third received sodium hyaluronate. Samples were processed and stained with $\mathrm{HE}$ and toluidine blue for morphological evaluation. The metabolic and proliferative activity of the chondrocytes was evaluated by the measurement of nucleolar organizer regions (NORs) after impregnation by silver nitrate. Significant differences were not observed $(\mathrm{P}>0.05)$ in the morphology among the groups, however, the group treated with sodium hyaluronate had a higher score suggesting a trend to a greater severity of the lesions. Significant differences were not observed $(\mathrm{P}>0.05)$ in the measurement of NORs, cells and NORs/cells among the groups. Although differences were not significant, sodium hyaluronate group showed higher NOR and cell counts which suggested an increase of the proliferation rate of chondrocytes. In addition, a higher NOR/cell ratio in the group treated with chondroitin sulfate suggested that this drug may have stimulated the metabolic activity of the chondrocytes, minimizing the lesions resulting from DJD.
\end{abstract}

Keywords: dog, degenerative joint disease, chondroitin sulfate, sodium hyaluronate, NOR

\section{RESUMO}

Foram utilizadas amostras de cartilagem articular do fêmur, tíbia e patela de 15 cães com doença articular degenerativa (DAD), induzida experimentalmente. Foram constituídos três grupos de cinco animais: grupo 1 controle, não medicado; grupo 2 - tratado com sulfato de condroitina e grupo 3 - tratado com hialuronato de sódio. As amostras foram processadas e coradas pelas técnicas de HE e de azul de toluidina para avaliação das alterações morfológicas, e impregnadas pelo nitrato de prata para análise da atividade metabólica elou proliferativa dos condrócitos, por meio da visualização e quantificação de regiões organizadoras do nucléolo (NORs). Não foram notadas diferenças significativas $(P<0,05)$ na avaliação morfológica entre os grupos. $O$ grupo tratado com hialuronato obteve maior escore sugerindo maior gravidade das lesões. Não foram observadas diferenças significativas $(P>0,05)$ na contagem de NORs, células e NORs/célula entre os grupos. As maiores contagens de NORs e de células no grupo tratado com hialuronato de sódio sugeriram aumento da taxa de proliferação dos condrócitos. A maior relação de NORs/célula obtida no grupo tratado com sulfato de condroitina sugere que essa droga estimula a atividade metabólica do condrócito, minimizando as lesões ocorridas durante a DAD.

Palavras-chave: cão, doença articular degenerativa, hialuronato de sódio, sulfato de condroitina, NOR

Recebido em 6 de junho de 2007

Aceito em 31 de janeiro de 2008

*Autor para correspondência (corresponding author)

E-mail: eliane@vet.ufmg.br

Apoio: FAPEMIG 


\section{INTRODUCTION}

Degenerative joint disease (DJD) consists in a slow and progressive degradation of the articular cartilage and it is the most common articular pathology in aging domestic animals and humans. It is a syndrome characterized by cartilage destruction, bone remodelation, osteophyte formation, changes in periarticular soft tissues and inflammation (Buckwalter and Mankin, 1997). Many of the responsible mechanisms for the progressive cartilage loss in DJD are still unknown, but the pathological process can be divided in three phases: changes in the extracellular matrix, chondrocytic response to tissue injury followed by decrease of chondrocytic anabolism and progressive loss of cartilaginous tissue (Mankin et al., 1971).

The main goals of medical therapy for DJD are to regenerate the cartilage and maintain the joint function, relieving pain and decreasing inflammation (Hanson, 1996; Barbucci et al., 2002). Traditionally, therapeutic objectives are reached through surgical and nonsurgical means. Surgery is indicated when the inciting cause can be physically removed or when the joint pain and the dysfunction can not be treated using conservative methods. Other treatments include resting, physiotherapy and drugs. Effective medical treatment should result in increase in anabolic response and decrease in catabolism and, consequently, delayed progression of DJD and improved repair of cartilaginous tissue (Altman et al., 1989). Chondroprotective agents might increase macromolecules synthesis, inhibit degradative enzymes and prevent fibrine formation in synovial fluid and membrane (Hanson, 1996).

The reported beneficial effects of chondroitin sulfate on articular cartilage include inhibition of degradative enzymes, metabolic stimulatory effect, inhibition of effects of Il-1 $\beta$, decrease in secretion of prostaglandin $E_{2}$ and inhibition of chondrocyte apoptosis. The effects of hyaluronic acid have been related to the increased synthesis by synoviocytes, inhibition of inflammation, improvement in chondrocyte density and metabolism, inhibition of apoptosis, prevention of degenerative injuries and improved of repairing process of the extracelular matrix (Smith and Gosh, 1987; Takahashi et al., 2000; Guidolin et al., 2001; Barbucci et al., 2002).
However, some reports have shown no deleterious effects (Smith et al., 1998; Melo et al., 2003; Biasi et al., 2005; Melo et al., 2008)

Therefore, the objective of this study was to investigate the mechanisms of action of sodium hyaluronate and chondroitin sulfate in articular cartilage in dogs undergoing DJD.

\section{MATERIAL AND METHODS}

Fifteen mature mongrel dogs, weighing 18 to $25 \mathrm{~kg}$ were used in this study. No abnormality of knee joint was radiographically confirmed. DJD was induced by section of the cranial cruciate ligament (CCL) through arthroscopy access on the left hindlimb. Three weeks later, arthrotomy and substitution of CCL were performed. The animals were distributed in three experimental groups with five animals each: the control group received no medication. Animals treated with chondroitin sulfate ${ }^{1}$ received $24 \mathrm{mg} / \mathrm{each}$, by intramuscular injection, six times at 5-day intervals. Sodium hyaluronate ${ }^{2}$ was administered three times, by endovenous injection, in dosage of $20 \mathrm{mg} /$ animal, at 5-day intervals. After 90 days, the animals were euthanized with sodium thiopental ${ }^{3}$ overdose and samples were collected for histological examination.

Full-thickness articular cartilage samples of femoral condyles, tibia and patella were collected. Specimens were fixed in $10 \%$ buffered formalin ( $\mathrm{pH}$ 7.4) for 24 hours, decalcified in $10 \%$ formic acid $(\mathrm{pH} 4.5)$ for 20 days, processed and embedded in paraffin. From the resulting tissue blocks, sections were cut $(4 \mu \mathrm{m})$ and placed on glass slides.

The articular cartilage of sampled sections were stained with hematoxylin and eosin and toluidine blue. They were evaluated under light microscopy and morphologically classified in accordance with Table 1, based on the histological scoring system of Mankin et al. (1971). In this study, grades of observed alterations were summed to graduate morphological lesions in each analyzed section.

\footnotetext{
${ }^{1}$ Artroglycan ${ }^{\circledR}$, Syntex S/A

${ }^{2}$ Legend ${ }^{\circledR}$, Bayer S/A

${ }^{3}$ Thionembutal ${ }^{\circledR}$, Cristália PFL Ltda.
} 
Table 1. Parameters of qualitative morphological evaluation of canine articular cartilage in experimentally induced DJD*

\begin{tabular}{lc}
\hline Features & Grade \\
\hline I - Cartilage structure & 0 \\
a) normal & 1 \\
b) fibrillation in the superficial zone & 2 \\
c) fibrillation in the middle zone & 3 \\
d) irregularities in the superficial zone & 4 \\
e) fissures & 5 \\
f) erosion & 6 \\
g) pannus & \\
\hline II - Cellularity & 0 \\
a) normal & 1 \\
b) diffuse hypercellularity & 2 \\
c) clones & 3 \\
d) hypocellularity & \\
\hline III - Toluidine blue staining & 0 \\
a) normal & 1 \\
b) slight reduction & 2 \\
c) moderate reduction & 3 \\
d) severe reduction & 4 \\
e) absent
\end{tabular}

*Modified by Mankin et al.,1971.

In order to measure the metabolic and proliferative activities of the chondrocytes, the sections were impregnated with silver nitrate to visualize the nucleolar organizer regions (NORs) (Ploton et al., 1986). The corresponding granules of NORs were counted in 40 microscopic fields per section, using the immersion objective in a light microscopy. The number of fields was defined by the instability test. Concomitantly, the number of chondrocytes was counted in each microscopic field. Four sections per animal were evaluated, totaling up to 800 fields per experimental group.

The morphometric data and the NORs and cells numbers were submitted to analysis of variance and the significance of the comparison among the means was evaluated by the Student Neuman Keuls test (SNK). The Kruskal-Wallis test was performed on the data distribution obtained by the morphological graduation of the articular cartilage (Sampaio, 2002).

\section{RESULTS AND DISCUSSION}

Some methods of classification have been considered to measure common morphological alterations of articular cartilage with DJD. These methods provide more refined comparisons, but they remain subjective. The table of evaluation elaborated for this study was based on a scoring system described by Mankin et al. (1971), however adaptations were made to emphasize the characteristics that demonstrated greater importance in the study carried out by Melo et al. (2003). The sum of all characteristics, analyzed in each histological section, allowed for a better evaluation of cartilage morphology, as well as, to characterize the phase of the DJD. The larger the sum of the score the more severe was the degenerative process in the articular cartilage. This evaluation was helpful in classifying the degenerate articular cartilage and it allowed to compare the effects of chondroitin sulfate and sodium hyaluronate.

In sections of all groups, the more frequent histological findings reflected the degenerative nature of this illness: presence of surface cartilage irregularities and fibrillation, edema, hypocellularity and decrease of the concentration of proteoglycans characterized by the reduction of staining intensity (Fig.1). Such changes observed in the DJD were also described by Mankin et al. (1971) and Melo et al. (2008). The articular instability possibly modified the intensity and distribution of forces in the articular cartilage, leading to the proteoglycans and collagens breakdown and, consequently, to the loss of matrix structure and to an increase in water content. The edema and the exposition of collagen type II fibrils caused a reduction in resistance and elasticity of the articular cartilage. These injuries to the structure of the cartilage produced death of the chondrocytes and initiated a repair response, resulting in chondrocyte proliferation.

Sandell and Aigner (2001) have described this limitation of the articular cartilage to counteract losses occurred during DJD, by the increase of chondrocyte proliferative activity.

When the alterations of the degenerate articular cartilage were evaluated, according to Table 1, such as irregularities, fibrillation, fissures, erosion, pannus, clones, hyper and hypocellularity (Fig. 2 and 3), it was not observed significant difference among the groups $(\mathrm{P}>0.05)$ (Table 2). Also, the evaluation of the metabolic and/or proliferative activity of the chondrocytes did not show statistical differences for the measurements of NORs, cells and NORs/cell ratio among the experimental groups $(\mathrm{P}>0.05)$ (Tables 3, 4 and 5). No significant differences among the sections of the same group 
and comparing similar sections of different groups were found (data not shown). Probably, in this study, the correction of the inciting caused by the substitution of CCL may have affected the development of the DJD. If permanent abnormal forces had remained on the injured cartilage, more serious degenerative alterations could have resulted and it would be possible to observe larger differences among the experimental groups. The removal of the inciting cause is infrequent in studies aimed to evaluate the effect of glicosaminoglycans, but this study followed ethical guidelines for animal experimentation (Coelho, 2000) and tried to simulate clinical practice. In addition, effects of chondroprotective agents could also have been influenced by concentration (Shehaan et al., 2003), molecular weight (Smith and Gosh, 1987), and presence of adverse environmental conditions (Willians et al., 2003). The characterization of NORs, according to their size, shape and clustering could be helpful to better discriminate differences among the experimental groups and, maybe, could be associated to proliferative or metabolic activity (Irazusta et al., 1998). Finally, in spite of the number of animals indicated by statistics, these results should be undertaken with caution due the small number of animals under evaluation.

Table 2. Means and standard deviations of the morphological evaluations of articular cartilage in DJD of control, chondroitin sulfate and sodium hyaluronate groups.

\begin{tabular}{cc} 
Group & Grade* \\
\hline Control & $12.75 \pm 4.39$ \\
Condroitin sulfate & $11.40 \pm 4.25$ \\
Sodium hyaluronate & $13.77 \pm 5.64$ \\
\hline *No statistical difference $(\mathrm{P}>0.05)$ & among grades by \\
Kruskall Wallis test. &
\end{tabular}

Morphological findings indicating a lesser intensity of changes in injured cartilage of animals treated with sodium hyaluronate were reported by Guidolin et al. (2001) and Barbucci et al. (2002). However, in this study, the mean score of the group treated with sodium hyaluronate was greater than those from the others groups (Table 2). It was result of a larger number of structural changes and a smaller proteoglycan content observed in the articular cartilage (Fig. 1c), suggesting higher severity. The absence of beneficial effect of the sodium hyaluronate on the structure of the degenerate articular cartilage was described by Smith et al. (1998) and Melo et al. (2008). Perhaps, the more severe degenerative changes observed in the articular cartilage of the dogs treated with sodium hyaluronate compared to those from the control group could be resulted, in part, of the administration access of this drug in this study. It cannot be affirmed which sodium hyaluronate medicated by intravenous injection reached the minimum effective concentration at the cartilaginous joint tissue, providing adequate action of this drug because the hyaluronic acid molecule has a plasmatic half-life of several minutes (Prestwich and Vercruysse, 1998). Moreover, sodium hyaluronate has a viscosupplementation effect when used by intraarticular via, which improves the viscosity of the synovial fluid, decreasing attrition and impact on the injured cartilage, however, this is a short duration effect (Balazs and Denlinger, 1993). Smith et al. (1998) did not observe improvement in the cartilage morphology using this drug by intraarticular access either.

By contrast, it was noticed that the mean score of the chondroitin sulfate group was smaller than from the control and sodium hyaluronate groups. It reflected the presence of less conspicuous degenerative injuries, assuming that chondroitin sulfate stimulated the reparative process or delayed the disease evolution. This beneficial effect on the degenerate cartilage was also described by Altman et al (1989), Biasi et al. (2005) and Melo et al. (2008).

In general, the characteristics of the articular cartilage described in this study indicated that the sampled tissue was between the repair phase (characterized by the proliferation of the chondrocytes and the increase of chondrocytic metabolic activity) and the beginning of the degenerative phase (when cellular death and reduction of anabolism predominate) (Mankin et al., 1971; Buckwalter and Mankin, 1997; Sandell and Aigner, 2001). Thus, the cartilage lesions in the group treated with chondroitin were less severe and less frequent suggesting the predominance of articular cartilage in the repair phase.

The impregnation by silver nitrate of tissue for visualization of NORs and its morphometric analysis were commonly reported in tumor or dysplastic tissues to analyze the proliferation and the cell metabolic activity rates (Ohno et al, 1991, Afolabi et al., 2001; Maki et al., 2001). This study also proved to be viable the evaluation of the chondrocytic activity in articular cartilage with DJD (Fig. 4). 


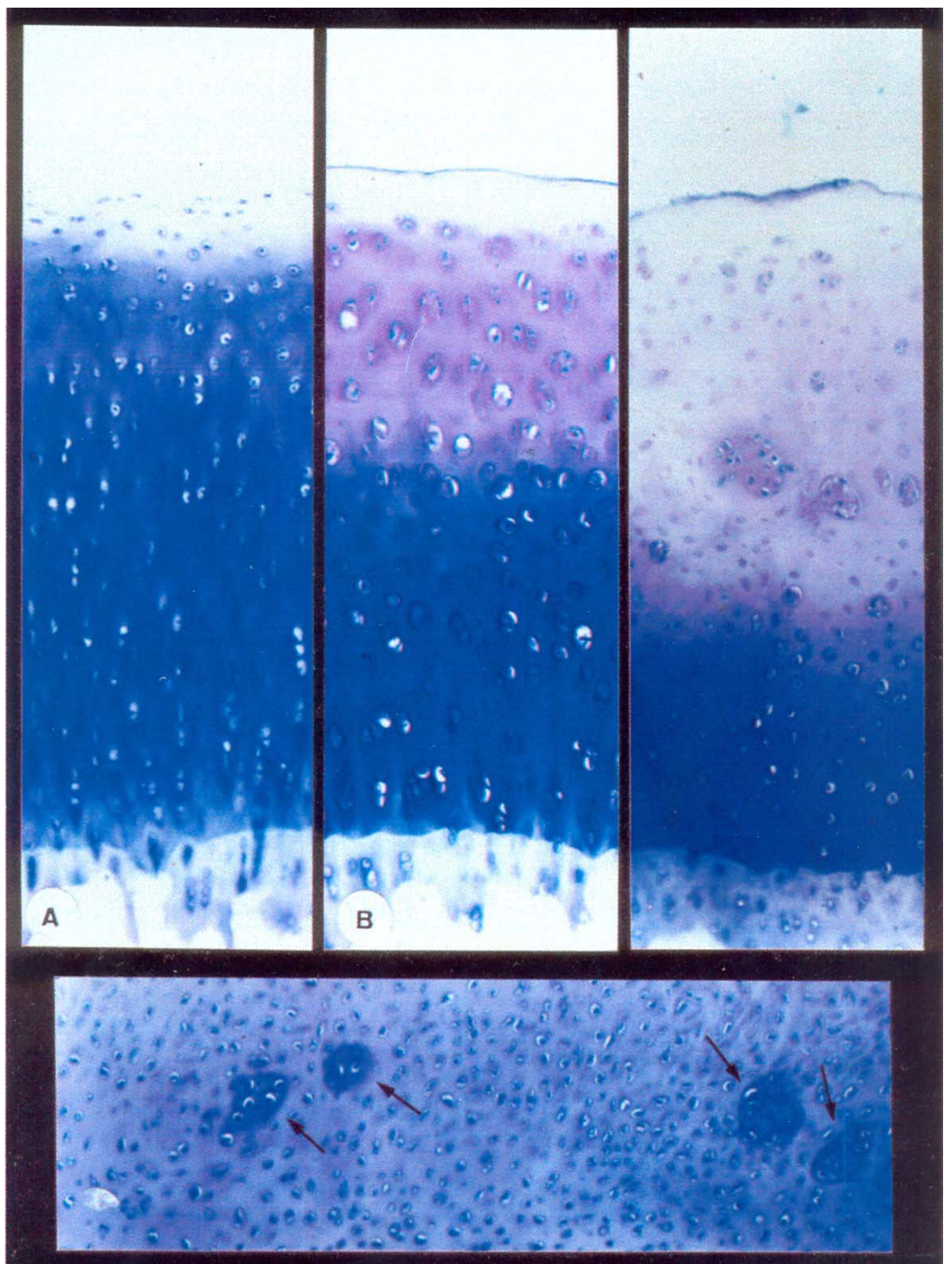

Figure 1. Progressive decrease of the staining intensity of the extracellular matrix of the articular cartilage of the femur of dogs. Toluidine blue. A) Slight. Condroitin sulfate group, 118.7x. B) Moderate. Sodium hyaluronate group. 118.7x. C) Severe. Sodium hyaluronate group, 143.5x. D) Areas showing synthesis of extracellular matrix (arrows). Sodium hyaluronate group, 119.9x. 


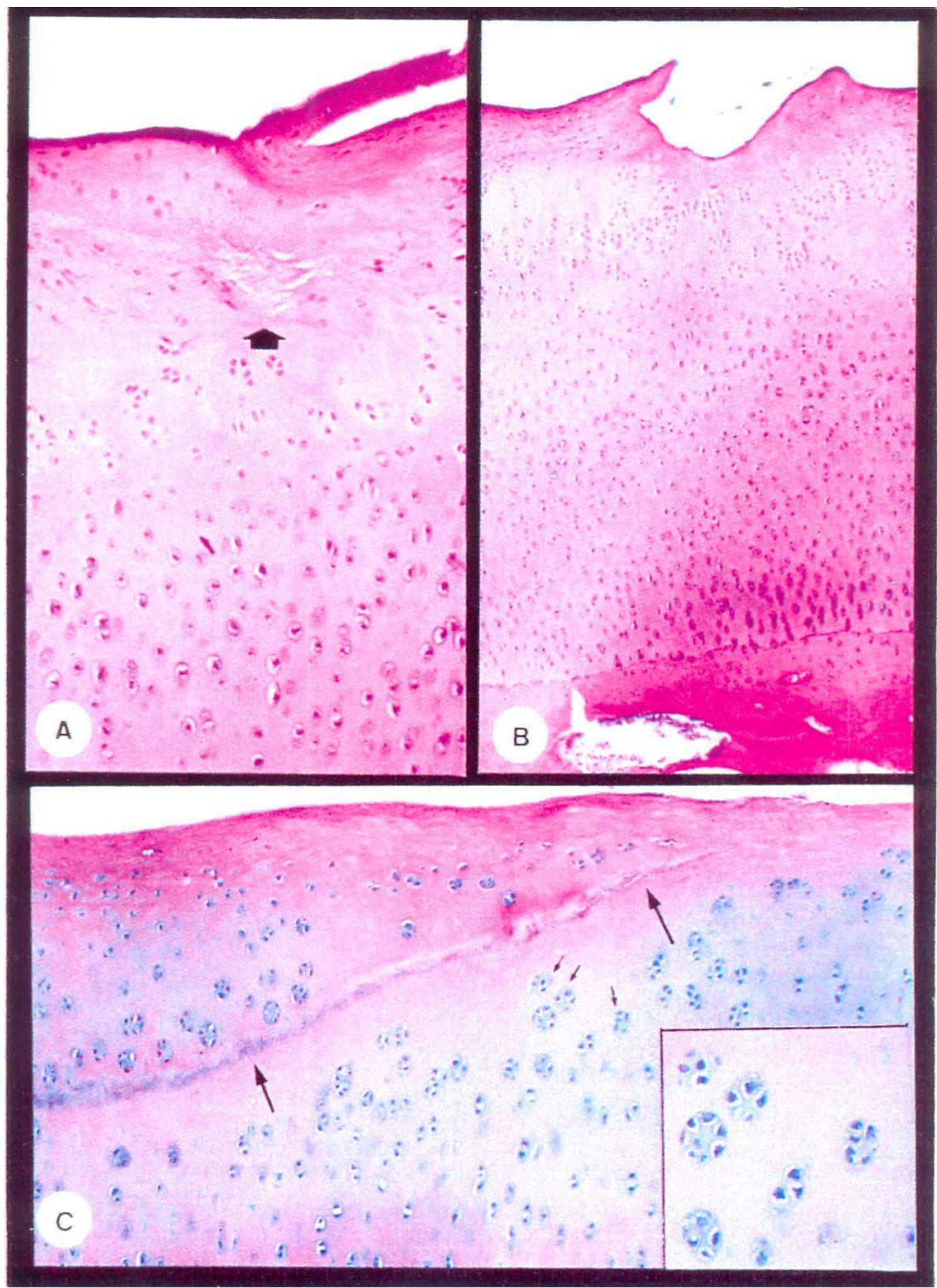

Figure 2. Degenerative changes in the articular cartilage of the femur of dogs. Control Group. HE. A) Fibrillation (arrow), 107.1x. B) Erosion, 64.7x. C) Fissure (larger arrows) and clones (smaller arrows), 107.1 $\mathrm{x}$ and in detail, 214.2x. 


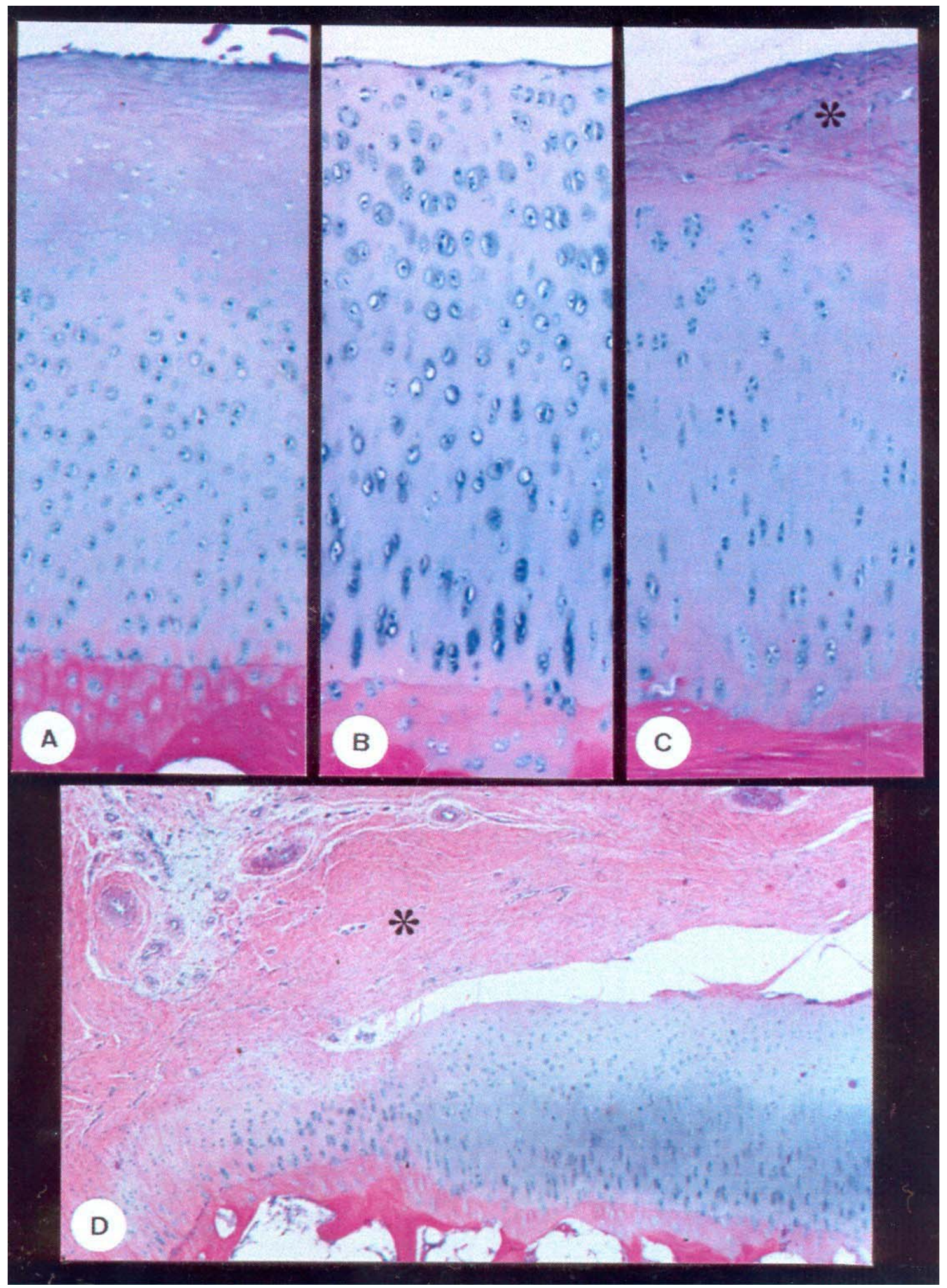

Figure 3. Degenerative changes in the articular cartilage of dogs. HE. A) Hypocellularity, Control group, 124.3x. B) hypercellularity. Condroitin sulfate group, 126.4x. C) Pannus (asterisk). Control group, 107.1x. D) Pannus (asterisk). Sodium hyaluronate group, 250.7x. 


\section{Gonçalves et al.}

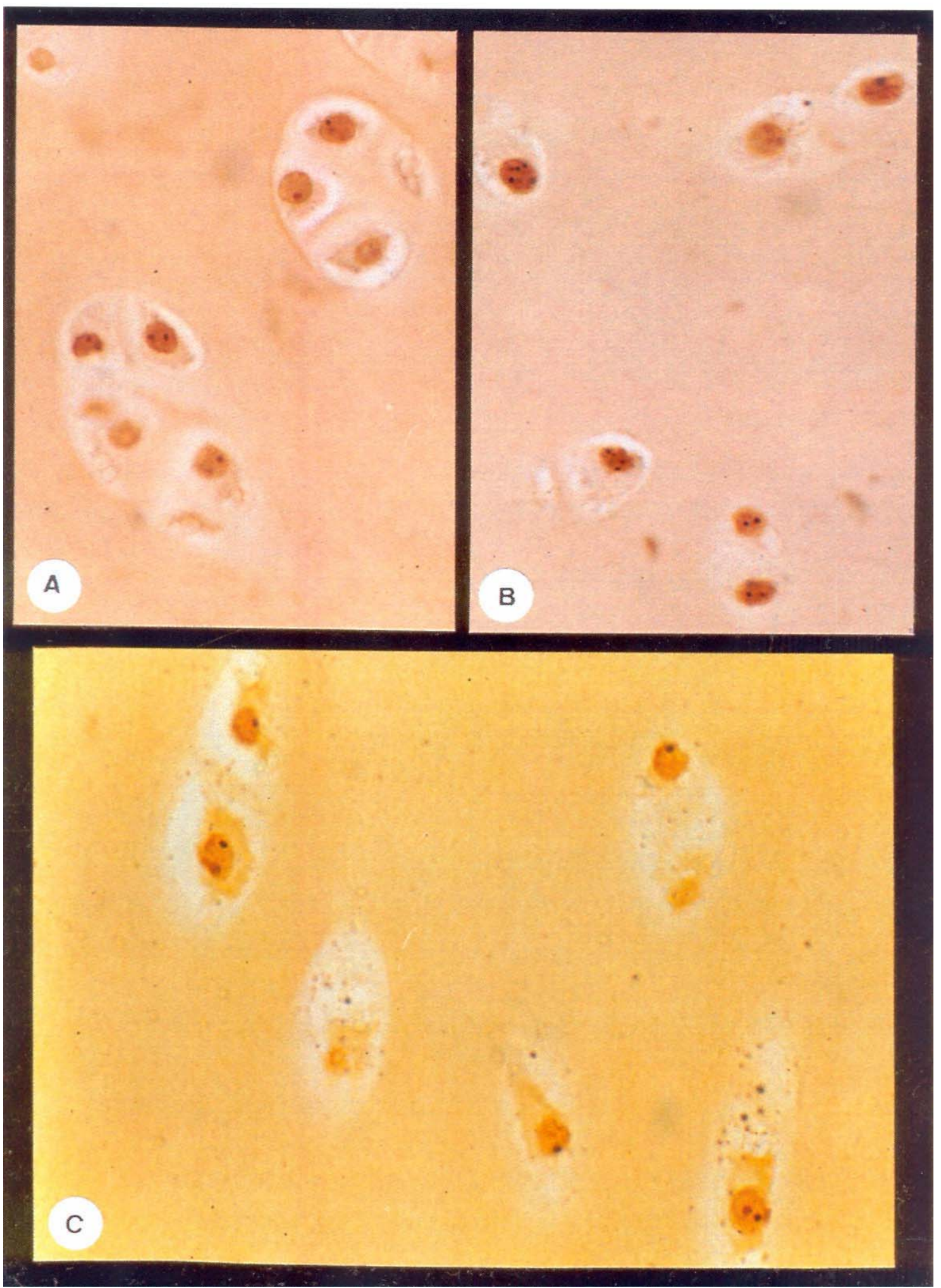

Figure 4. Nucleolar organizer regions in chondrocytes of the degenerate articular cartilage of dogs. Impregnation by silver nitrate. A) Control group. Patella, 1071.4x. B) Chondroitin sulfate group. Femur, 1071.4x. C) Sodium hyaluronate group. Tibia, 1229.9x. 
Table 3. Means and standard deviations of NOR numbers in sections of articular cartilage of dogs with DJD of control, chondroitin sulfate and sodium hyaluronate groups

\begin{tabular}{cc}
\hline Group & NORs \\
\hline Control & $883.11 \pm 435.62$ \\
Condroitin sulfate & $981.55 \pm 291.04$ \\
Sodium hyaluronate & $1122.95 \pm 445.21$ \\
\hline
\end{tabular}

No statistical difference ( $\mathrm{P}>0.05)$ was observed among the groups when applying the SNK test.

Table 4. Means and standard deviations of cell numbers in sections of articular cartilage of dogs with DJD of control, chondroitin sulfate and sodium hyaluronate groups

\begin{tabular}{cc}
\hline Group & Cells \\
\hline Control & $576.44 \pm 229.22$ \\
Condroitin sulfate & $583.90 \pm 135.14$ \\
Sodium hyaluronate & $688.47 \pm 224.66$ \\
\hline No statistical difference $(\mathrm{P}>0.05)$ was observed \\
among the groups when applying the SNK test.
\end{tabular}

Table 5. Means and standard deviations of the NORs/cell ratio in sections of articular cartilage of dogs with DJD of control, chondroitin sulfate and sodium hyaluronate groups

\begin{tabular}{cc}
\hline Group & NOR/cell \\
\hline Control & $1.54 \pm 0.29$ \\
Condroitin sulfate & $1.70 \pm 0.25$ \\
Sodium hyaluronate & $1.64 \pm 0.31$ \\
\hline
\end{tabular}

No statistical difference ( $\mathrm{P}>0.05)$ was observed among the groups when applying the SNK test.

The NOR number mean was higher in the group treated with sodium hyaluronate than in the control and chondroitin sulfate groups, suggesting that this drug stimulated the chondrocyte activity in the degenerate cartilage. Furthermore, the highest mean of cell numbers was observed in this group. Therefore, these findings suggest, that sodium hyaluronate stimulated the proliferation of chondrocytes, preferably, or could be derived from the inefficiency of this drug to reduce the severity of DJD (Table 2), which usually leads to the stimulation of cell proliferative response in a compensatory effort. This increase of cellular density in the articular cartilage of the animals submitted to the treatment with hyaluronic acid was also described for Guidolin et al. (2001),
Barbucci et al (2002) and Melo et al. (2008). Inhibition of apoptosis may be another responsible mechanism which resulted in higher numbers of chondrocytes in the treatment with sodium hyaluronate (Takahashi et al., 2000).

During the degenerative process, the chondrocytes increase the synthesis of matrix components in an attempt to compensate for greater degradation of structural elements (Matyas et al., 1999). A higher NORs/cell ratio was observed in the chondroitin sulfate group, suggesting a higher metabolic and/or proliferative activity. However, mean of cell counts in the chondroitin sulfate group was inferior than the sodium hyaluronate group and similar to the control group. Thus, it may suggest that the higher NORs/cell ratio observed in the chondroitin sulfate group resulted mainly from the higher metabolic activity of the chondrocytes. It may also be responsible for the better maintenance of the matrix. Bassleer et al. (1998) and Verbruggen et al. (1999) observed an increase in the synthesis of proteoglycans by chondrocytes when DJD was treated with sulfated glicosaminoglycans.

In conclusion, this study suggests that sodium hyaluronate increased the proliferation rate of chondrocytes in the articular cartilage of dogs with DJD. However, apparently, it was not able to decrease the degeneration process, while chondroitin sulfate stimulated the chondrocytic metabolic activity and was possibly helpful to decrease the degenerative process.

\section{REFERENCES}

AFOLABI, O.C.; ODUKOYA, O.; AROLE, G. et al. Nucleolar organizer regions in jaw tumours of cartilage origin. West Afr. J. Med., v.20, p.17-21, 2001

ALTMAN, R.D.; MUNIZ, O.E.; HOWELL, D.S. Therapeutic treatment of canine osteoarthritis with glycosaminoglycan polysulfuric acid ester. Arth. Rheum., v.32, p.1300-1307, 1889.

BALAZS, E.A.; DENLINGER, J.L. Viscosupplementation: a new concept in the treatment of osteoarthritis. J. Rheumatol. v.20, suppl. 39, p.3-9, 1993.

BARBUCCI, R.; LAMPONI, S.; BORZACCHIELLO, A. et al. Hyaluronic acid hydrogel in the treatment of osteoarthritis. Biomaterials, v.23, p.4503-4513, 2002. 
BASSLEER, C.; ROVATI, L.; FRANCHIMOT, P. Stimulation of proteoglycan production by glucosamine sulfate in chondrocytes isolated from human osteoarthritic articular cartilage in vitro. Osteoarth. Cart., v.6, p.427-434, 1998.

BIASI, F.; RAHAL, S.C.; VOLPI, R.S. et al. Reconstrução do ligamento cruzado craneal em cães, associado ou não ao sulfato de condroitina. Arq. Bras. Med. Vet. Zootec., v.57, p.442-447, 2005.

BUCKWALTER, J.A.; MANKIN, H.J. Articular cartilage. Part II: Degeneration and osteoarthrosis, repair, regeneration and transplantation. J. Bone Joint Surg., v.79-A, p.612-632, 1997.

COELHO, R.F. Experimentaçäo com animais: ética e legislaçäo. Rev. Hosp. Univ., v.10, p.3-15, 2000.

GUIDOLIN, D.D.; RONCHETTI, I.P.; LINI, E. et al. Morphological analysis of articular biopsies from randomized, clinical study comparing the effects of 500-730 kDa sodium hyaluronate (Hyalgan $\left.{ }^{\circledR}\right)$ and methylpredinisolone acetate on primary osteoarthritis of the knee. Osteoarth. Cart., v.9, p.371-381, 2001.

HANSON, R.R. Oral glycosaminoglycans in treatment of degenerative joint disease in horses. Equine Pract., v.18, p.18-22, 1996.

IRAZUSTA, S.P.; VASSALO, J.; MAGNA, L.A. et al. The value of PCNA and AgNOR staining in endoscopic biopsies of gastric mucosa. Pathol. Res. Pract.,v.194, p.33-39, 1998.

MAKI, M.; SAITHO, K.; HORIUCHI, H. et al. Comparative study of fibrous dysplasia and osteofibrous dysplasia: histopathological, immunohistochemical, argyrophilic nucleolar organizer region and DNA ploidy analysis. Pathol. Int., v.51, p.603-611, 2001.

MANKIN, H.J.; DORFMAN, H.; LIPIELLO, N. et al. Biochemical and metabolic abnormalities in articular cartilage from osteo-arthritic human hips II: Correlation of morphology with biochemical and metabolic data. J. Bone Joint Surg. Am., v.53-A, p.523-537, 1971.

MATYAS, J.R.; EHLERS, P.F.; HUANG, D. et al. The early molecular natural history of experimental osteoarthritis. I. Progressive discoordenate expression of aggrecan and type II procollagen messenger RNA in the articular cartilage of adult animals. Arth. Rheum., v.42, p.993-1002, 1999.

MELO, E.G.; C.M.F. REZENDE; GOMES, M.G. et al. Sulfato de condroitina e hialuronato de sódio no tratamento da doença articular degenerativa experimental em cães. Aspectos clínicos e radiológicos. Arq. Bras. Med. Vet. Zootec., v.55, p.3543, 2003.

MELO, E.G.; NUNES, V.A.; REZENDE, C.M.F. et al. Sulfato de condroitina e hialuronato de sódio no tratamento da doença articular degenerativa em cães. Estudo histológico da cartilagem articular e membrana sinovial. Arq. Bras. Med. Vet. Zootec., v.60. p.83-92, 2008.

PLOTON, D.; MENAGER, M.; JEANNESSON, P. et al. Improvement in the staining and in the visualization of the argyrophilic nucleolar organizer regions at the optical level. Histochem. J., v.18, p.514, 1986.

PRESTWICH, G.D.; VERCRUYSSE, K. Profiles therapeutic applications of hyaluronic acid and hyaluronan derivates. PSTT, v.1, p.42-43, 1998.

SANDELL, L.J.; AIGNER, T. Articular cartilage and changes in arthritis. An introduction: cell biology of osteoarthritis. Arth. Res., v 3, p.107-113, 2001.

SAMPAIO, L.B.M. Estatística aplicada à experimentação animal. 2.ed. Belo Horizonte: FEPMVZ, 2002. 265p.

SHEEHAN, K.M.; DELOT, L.B.; DAY, S.M. et al. Hyalgan ${ }^{\circledR}$ has a dose-dependent differencial effect on macrophage proliferation and cell death. J. Orthop. Res., v.21, p.744-751, 2003.

SMITH, M.M.; GHOSH, P. The synthesis of hyaluronic acid by human synovial fibroblasts is influenced by the nature of the hyaluronate in the extracelular environment. Rheumatol. Inter., v.7, p.113-122, 1987.

SMITH, G.N.; MYERS, S.L.; BRANDT, K.D. et al. Effect of intraarticular hyaluronan injection in experimental canine osteoarthritis. Arth. Rheum., v.41, p.976-985, 1998.

TAKAHASHI, K.; HASHINOMOTO, S.; KUBO, T. et al. Effect of hyaluronan on chondrocyte apoptosis and nitric oxide production in experimentally induced osteoarthritis. J. Rheum., v.27, p.1713-1720, 2000.

VERBRUGGEN, G.; CORNELISSEN, M.; ELEWAUT, D. et al. Influence of polysulfated polyssacarides on aggrecans synthetized by differentiated human articular chondrocytes. $J$. Rheumat, v.27, p.1663-1671, 1999.

WILLIANS, J.M.; RAYAN, V.; SUMMER, D.R. et al. The use of intraarticular Na-hyaluronate as a potential chondroprotective in experimentally induced acute articular cartilage injury and repair in rabbits. $J$. Orthop. Res., v.21, p.305-311, 2003. 